Тимошенко Р. І., д.військ.н., с.н.с;

Федорієнко В. А.;

Прокопенко О. С.

Центр воєнно-стратегічних досліджень Національного університету оборони України імені Івана Черняховського, Київ

\title{
Аспекти практичної реалізації макету інформаційно- аналітичної системи фіксації обстрілів для Української сторони СЦКК
}

Резюме. Стаття розкриває особливості практичної реалізації макету інформаційно-аналітичної системи фіксації обстрілів для чергових служб, діяльності штабу та українських спостерігачів Української сторони Спільного центру з контролю та координації питань припинення вогню та стабілізації лінії розмежування сторін на основі використання інструментарію ГІС та системи управління базами даних.

Ключові слова: системи фіксації обстрілів, ГІС, СУБД.

Постановка проблеми. Спільний центр 3 контролю та координації питань припинення вогню та стабілізації лінії розмежування сторін (СЦКК), утворений Генеральним штабом Збройних Сил України за розпорядженням Президента України "Про забезпечення моніторингу i верифікації режиму незастосування зброї”, виконує функції щодо забезпечення взаємодії державних органів України, вищого командування Збройних Сил (3С) України та інших військових формувань i правоохоронних органів України, уповноважених представників інших зацікавлених сторін зі Спеціальною моніторинговою місією ОБСЕ 3 питань визначення пріоритетів у здійсненні моніторингу дотримання режиму незастосування зброї та його верифікації, узгодження питань забезпечення безпеки співробітників та технічного обладнання Спеціальної моніторингової місії (CMM) ОБСЄ, обміну інформацією щодо порушень режиму незастосування зброї та підготовки пропозицій для невідкладного реагування на такі порушення. Також, СЦКК разом із СММ $\epsilon$ ключовими при створенні механізму розведення сил і засобів вздовж лінії зіткнення [1].

Отже, у наслідок осмислення сутності діяльності та алгоритмів дій штабу СЦКК було проведено роботу з раціоналізації збору даних для їх подальшого аналізу та відображення на електронній карті. Аналіз виконання функціональних обов'язків офіцерами СЦКК виявив низький рівень автоматизації, із переважно ручним способом (у т. ч., за допомогою обчислювальної техніки), функціональних процесів роботи штабу. Ініціативно було запропоновано робочий макет інформаційно-аналітичної системи фіксації обстрілів (ІАСФ), яка певною мірою підвищить рівень автоматизації i реалізує механізм швидкої візуалізації та аналізу обстановки на рівні бази даних для забезпечення інформаційних потреб штабу Української сторони СЦКК.

При створенні зазначеної IAC потрібно визначитися із іiі завданнями, топологією, архітектурою та місцем у структурі СЦКК.

Ступінь розробленості проблеми. За опублікованими матеріалами на сайті ОБСЄ можна ознайомитися 3 деякими прикладами щодо використання матеріалів, отриманих 3 географічної інформаційної системи (ГІС) [2]. Визначенню ролі подібної системи до ІАСФ (з погляду наявності ГІС-складової), яка б одночасно задовольняла вимоги ЗС України та відповідала би концепціям і стандартам НАТО присвячена робота [3]. Проблемам автоматизації штабів присвячена методика професора Городнова В. П. [4]. Проте практичній реалізації наукових напрацювань у цих роботах приділено обмаль уваги.

Метою статті є висвітлення основних аспектів практичної реалізації макету інформаційно-аналітичної системи фіксації обстрілів для Української сторони СЦКК.

Виклад основного матеріалу. Задача створення макету ІАСФ у складі Української сторони Спільного центру 3 контролю та координації питань припинення вогню та стабілізації лінії розмежування сторін (УС СЦКК) полягала у підвищенні: 
- ефективності несення служби чергових змін (УС СЦКК) та офіцерів спостерігачів спостережних груп;

- оперативності щодо збору, передачі та відображення на електронній карті зафіксованих фактів порушення режиму припинення вогню;

- точності розміщення об'єкта на карті (у т. ч. збереження точності при конвертації 3 однісї системи координат в іншу) за рахунок єдиного підходу до формування електронної карти СЦКК і картографічних документів для УС СЦКК у визначеному і затвердженому в ЗС України [5] програмному забезпеченні ГІС (ArcGIS).

Для формалізації проходження інформації від спостерігачів до штабу СЦКК було враховано поточний стан інформаційного середовища. Мережева складова цього середовища, для передачі даних про факт обстрілу з боку незаконних збройних формувань (НЗФ), в УС СЦКК розглядалася, як відкрита інформація, що дає змогу використовувати інформаційнотелекомунікаційну мережу Інтернет.

Розподіл рівнів вузлів даних інформаційного середовища УC СЦКК ієрархічно містить такі рівні:

- спостережних постів;

- спостережних груп;

- відділу чергових змін;

- інформаційно-аналітичної групи.

Ця ієрархія вузлів проходження інформації про обстріли збоку НЗФ полягає в основі роботи центру. 3 урахуванням іiі особливостей було проведено визначення підходів до візуалізації обстрілів на електронній карті з їх подальшим швидким аналізом. Ручне нанесення обстрілів (поодному) за добу на електронну карту є доволі складним процесом особливо за умови значної щоденної кількості обстрілів. Звідси виникла потреба у пакетному завантаженні даних про обстріли. Єдиних підходів у формуванні щоденних звітних таблиць чергових змін не було, спостерігалася слабка структурованість даних. Вирішенням цього стало упорядкування даних на рівні БД 3 їх подальшим завантаженням до ГІС.

Крім того, для створення макету ІАСФ було вирішено низку наукових, прикладних та організаційно-підготовчих завдань:

- здійснено формалізацію процесів діяльності СЦКК для їх реалізації в макеті програмного комплексу;

- підготовлено географічну базу даних 3 використанням електронної карти;
- проведено дослідження проблемних питань автоматизації процесів збору, реєстрації, зберігання, аналізу і відображення на електронній карті фактів порушення режимів припинення вогню;

- виконано завдання щодо підготовки картографічних документів.

Для створення макету ІАСФ були проведені такі кроки:

- формалізація даних в інформаційному середовищі, для мінімізації появи помилок у реляційній системі управління базами даних (СУБД) внаслідок людського фактора;

- автоматизація процесів імпортуекспорту даних у ГІС для висвітлення поточної обстановки наслідків порушення припинення вогню на електронній карті;

- інтеграція процесів обміну даними 3 мобільними ГІС;

- інтеграція процесів обміну даними через ГІС-колектори;

- автоматизоване

формування регламентованої (нерегламентованої) звітності.

Розроблений макет ІАСФ включає у себе пакет 3 програмним забезпечення (ПЗ) та спеціальним програмним забезпеченням. Тому, ІАСФ умовно можна поділити на дві складові: реляційну БД та ГІС (містить статичну та мобільну складові).

Використання релящійної СУБД дає змогу здійснювати: формалізацію даних; консолідацію інформації в єдиному джерелі даних; автоматизацію процесу підтвердження даних про обстріли спостерігачами СЦКК; проведення швидкого аналізу (зрізів інформації) за визначений проміжок часу; використання накопиченої у БД інформації для подальшого використання в аналітичних системах підтримки прийняття рішень вищим командуванням.

Статична складова ГІС (інсталяція на стаціонарних ПЕОМ чи сервері) надає можливість: відображення поточної обстановки на карті, ऑiі оперативної зміни у разі необхідності; автоматизованої візуалізації фактів порушення режиму припинення вогню за рахунок інтеграції СУБД та аналітичних зрізів інтенсивності обстрілів; автоматизованого формування стандартизованих картографічних документів, які доводять використання НЗФ забороненої Мінськими домовленостями зброї, схеми проведення відновлювальних робіт на пошкоджених терористами об'єктах інфраструктури та промисловості.

Впровадження мобільної ГІС (інсталяція на мобільних пристроях) дасть змогу 
здійснити: оперативний збір інформації про обстріли офіцерами-спостерігачами одночасно 3 декількох напрямків за допомогою геоінформаційних колекторів і консолідацію зібраної інформації у єдиному джерелі даних за рахунок використання хмарних технологій; використати бібліотеки умовних знаків для нанесення об'єктів спостереження; оперативну зміну поточної обстановки на електронній карті та іiі експорт на інші пристрої мобільної та стаціонарної ГІС; прив'язку до місцевості за допомогою GPSприймача, прокладання маршрутів руху; фотофіксацію 3 автоматичним визначенням наслідків застосування НЗФ забороненої Мінськими домовленостями озброєння.

Упорядкування роботи чергових змін та аналітичної групи УС СЦКК здійснюється за рахунок використання реляційної БД. Використавши для макету можливості ПЗ Microsoft Access було розроблено автоматизоване робоче місце (АРМ) чергового офіцеру УС СЦКК та АРМ офіцера інформаційно-аналітичної групи. Ця СУБД використовувалась у макеті як система збору початкових даних про обстріли, їх обробку та експорт даних до ГІС 3 можливістю автоматизованої підготовки встановлених форм статистичних та аналітичних звітів про обстріли.

Вибір ГІС для розв'язання задачі візуалізації здійснено 3 врахування вимог військового стандарту [5] та охоплення максимальної функціональності СЦКК. Було обране ПЗ ArcGIS, яке стало ядром (основою) при створенні макету ІАСФ. Пакет геоінформаційних програм сімейства ArcGIS має такі блоки - настільну ГІС, ГІС-колектор на мобільних пристроях, ГІС-портал організації УС СЦКК, зовнішні локальні ГІС.

Блок настільної ГІС (обстановка, локатори, 3D модель, медіа геолокація) включає ПЗ ArcGIS (ESRI) ArcMap, ArcCatalog, ArcScene, блок ГІС колектора на мобільних пристроях - ПЗ Collector for ArcGIS, блок хмарного порталу організації УC СЦКК - ПЗ ArcGIS Online тa Viewer ArcGIS Online, блок зовнішніх локальних ГІС - ПЗ ArcGIS ArcExplorer.

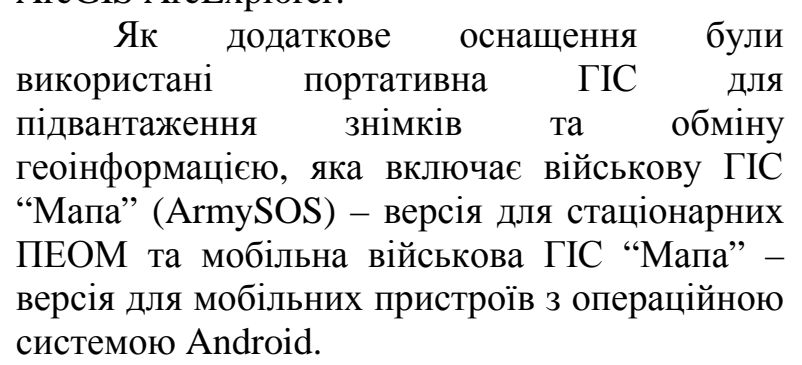

Зазначимо, що такі документи, як Мінський меморандум від 19.09.2014, Комплекс заходів 3 виконання Мінських домовленостей від 12.02.2015, Доповнення у частині, що стосується відведення танків, а також артилерійських гармат калібром до $100 \mathrm{mм} \mathrm{i} \mathrm{мінометів} \mathrm{калібром} \mathrm{до} 120 \mathrm{mм}$ (включно) від 29.09.2015 містять основні вихідні дані для електронної карти СЦКК, а саме: межі та зони припинення вогню в окремих районах Донецької i Луганської областей (ОРДЛО); відведення сторонами всіх важких озброєнь на рівні відстані 3 метою утворення зони безпеки завширшки мінімум 50 км (для артилерійських систем калібром 100 мм і більше), 70 км (для РСЗВ), 140 км (для реактивних систем залпового вогню "ТорнадоC", "Ураган", "Смерч" і тактичних ракетних систем "Точка-У”). Також, були нанесені межі та зони відведення всіх типів і модифікацій танків, артилерійських гармат калібром до 100 мм і мінометів калібром до 120 мм (включно) на рівні відстані з метою створення зони безпеки завширшки мінімум 30 км; для Збройних Сил України відведення зазначеного озброєння - від фактичної лінії зіткнення; для НЗФ ОРДЛО - від лінії зіткнення відповідно до Мінського меморандуму від 19.09.2014; райони відведення озброєння, які підпадають під дію Доповнення.

Створена електронна карта в ArcGIS включає спеціальні шари 3 точковими, лінійними та площинними умовними знаками із наповненим атрибутивним вмістом, а саме: елементи СЦКК та СММ ОБСЕ; фактична лінія зіткнення; елементи умов Мінських домовленостей 2014 і 2015 pp. (лінія зіткнення; точки місцевості (викл., вкл.), що визначають проходження цієї лінії; віддаленості відведення озброєння по обидві сторони від лінії зіткнення у вигляді буферних зон за видами озброєння); об'єкти (населені пункти), де були здійсненні обстріли (у якості локаторів для геокодування); межі й зони відповідальності спостережних груп; шаблонні кільцеві буферні зони дальностей ураження зразків артилерійських систем для перевірки відомостей та недопущення фальсифікації; точкові об'єкти 3 медіавмістом (фото, відео); растри висот 3 відмивкою рельєфу, із зонами видимості та взаємної видимості для кожного спостережного посту (СП) вздовж фактичної лінії зіткнення; об'єкти проведення ремонтно-відновлювальних робіт.

У польових умовах було перевірено можливість використання ГІС колектора для збору фактів порушення припинення вогню. У 
макеті він реалізований на П3 Collector for ArcGIS (додаток для мобільних пристроїв 3 операційними системами Android та iOS). Це рішення функціонує на основі захищеного хмарного ресурсу ArcGIS Online. Для цього, у настільному ПЗ ArcMap було підготовлено географічну базу даних із визначеною структурою полів для фіксації на нашому боці лінії зіткнення наслідків обстрілів (порушень). Створений шар 3 географічною БД, необхідний для збору, має підготовлені категоріальні символи для відображення порушень за типами застосованого озброєння противником і можливість наповнення фотографіями. Цей шар було розміщено на картографічному тестовому порталі організації УС СЦКК на хмарному ресурсі ArcGIS Online. При цьому перегляд ресурсу можливий лише за умови введення унікальних імені та пароля користувача.

Внесення фактів порушення спостерігачами, наслідків обстрілів (у т. ч. із приєднаним медіавмістом), можливий через встановлений додаток Collector for ArcGIS на свій пристрій (смартфон, планшет, ноутбук). У цій програмі, на раніше завантаженій базовій карті (знімку), можна встановити точковий символ наслідку обстрілу i заповнити форму (що була раніше підготовлена i опублікована за допомогою ArcМap) поза зоною дії Інтернету, тобто працювати у режимі офлайн. 3 появою мобільного пристрою спостерігача в зоні Інтернету i провівши синхронізацію 3 основним сервером, нанесені (зібрані) об'єкти фактів обстрілу стають доступними на робочому місці офіцера штабу УС СЦКК (за умови підключення до інтернету) в програмі ArcMap, або через web браузер у в’ювері (Viewer) ArcGIS Online.

Аналітика ГІС-складової реалізована у підходах до візуалізації на карті під час доповідей та підготовці звітних аналітичних матеріалів. Використання прямого з'єднання ГІС-складової 3 БД дає змогу не лише візуалізувати статистичні дані за категоріями у відповідних умовних знаках, але і проводити аналітичні розрахунки, наповнюючи їx просторовим змістом. На цей час реалізовані такі функції:

- побудова стовбчастих графіків частоти використання озброєння за типами по об’ єктах місцевості;

$$
\text { - візуалізація за допомогою }
$$

пропорційності символів частоти обстрілів об' єктів місцевості на нашому боці, по яким вівся вогонь;
- візуалізація $3 a$ допомогою пропорційності символів частоти появи об' єктів місцевості на боці противника, звідки вівся вогонь;

- використання аналізу часових показників для уточнення ступеню ураження різним типом озброєння із встановленою кількістю боєприпасів противника по об'єктах місцевості на нашому боці;

- проведення аналізу за часовими показниками випадків, зафіксованими черговими змінами УССЦКК, щодо місць ураження та напрямків обстрілів 3 важкого озброєння звідки вівся вогонь, шляхом відтворення хронологічного треку змін обстановки за допомогою інструмента мітки часу в ArcMap;

- візуалізація частоти обстрілів 3 боку НЗФ та порівняння їх у часі;

- визначення ділянок місцевості на території ОРДЛО прихованого використання озброєння, яке мало бути відведеним та підготовка відповідних інформаційних матеріалів для СММ ОБСЕ.

Як розширений функціонал ІАСФ було розроблено 3D моделі ділянок місцевості для СП та буферної зони шириною 30 км вздовж лінії розмежування сторін шляхом побудови TIN моделі та растрів висот із використання інструментарію фокальної статистики.

Отже, практична реалізація ІАСФ в УC СЦКК була продемонстрована при виконанні спеціальних завдань таких, як:

- розроблення маршрутів руху для виїзних груп УС СЦКК;

- створення макетів схем (картографічних документів у pdf-форматі з нанесеною сіткою у визначеній системі координат) ремонтновідновлювальних робіт відносно фактичної лінії розмежування;

- створення схем з нанесеними об' єктами обстрілу 3 вимірами їх взаємної відстані та дальності уражень видів озброєння заборонених Мінськими домовленостями;

$$
\text { - створення фотосхем місць }
$$

розташування СП УС СЦКК;

- створення схем зон видимості для кожного СП УС СЦКК;

- створення робочих схем зон безпеки (демілітаризованих зон);

- нанесення ймовірних джерел ведення вогню противника для надання пропозицій для огляду цих ділянок місцевості представникам СММ ОБСЕ.

Висновки. Отже, у статті розкрито основні аспекти практичної реалізації макету інформаційно-аналітичної системи фіксації 
обстрілів для Української сторони СЦКК. Використання макету ІАСФ підвищить ефективність несення служби чергових змін УС СЦКК та офіцерів-спостерігачів; оперативність збору, передачі та відображення на електронній карті зафіксованих фактів порушення режиму припинення вогню; точність (визначення координат, проведення вимірів довжин та площ, нанесення об'єктів на карту) та запровадить єдиний підхід до формування електронної карти СЦКК i картографічних документів для УС СЦКК.

Подальші дослідження слід присвятити визначенню ефективності моделі даних ("То Ве") УС СЦКК із використанням ІАСФ, у порівнянні 3 існуючою моделлю даних (“As Is").

\section{СПИСОК ВИКОРИСТАНОЇ ЛІТЕРАТУРИ}

1. Рамочное решение Трёхсторонней контактной группы о разведении сил и средств [Електронний pecypc] // OSCE CMM of Ukraine. - 2016. - Режим доступу до ресурсу: http://www.osce.org/ru/cio/266271?download=true.
2. Thematic Report. Civilian casualties in eastern Ukraine 2016 [Електронний ресурс] // OSCE CMM of Ukraine. - 2016. - Режим доступу до ресурсу: http://www.osce.org/special-monitoring-mission-toukraine/342121?download=true.

3. Федорієнко В. А. Особливості сучасної концептуальної архітектури ГІС платформи військового призначення / В.А. Федорієнко, О. В. Головченко, С. І. Васюхно. // Збірник наукових праць Центру воєнно-стратегічних досліджень Національного університету оборони України імені Івана Черняховського. - 2017. - №2. - С. 60-67.

4. Городнов В. П. Моделирование боевых действий частей, соединений и объединений войск ПВО. Пособие / Вячеслав Петрович Городнов. Харьков: Академия ПВО им. Маршала Говорова Л. А., 1987. - 387 с.

5. Військовий стандарт 01.110.001. Топогеодезичне забезпечення. База даних картографічної інформації для створення та використання в геоінформаційних системах ArcGIS / Військ. стандарт України. - Вид. 1. - [Чинний від 2011-1014]. - Київ : Міністерство оборони України, 2011. -112 c.

Стаття надійшла до редакції 09.11.2017

Тимошенко Р. И., Д.воен.н., с.н.с.;

Федориенко В. А.;

Прокопенко А. C.

Центр военно-стратегических исследований Национального университета обороны Украины имени Ивана Черняховского, Киев

Аспекты практической реализации макета информационно-аналитической системы фиксации обстрелов для Украинской стороны СЦКК

Резюме. Статья раскрывает особенности практической реализации макета информационноаналитической системы фиксации обстрелов для дежурных служб, деятельности штаба и украинских наблюдателей Украинской стороны Совместного центра по контролю и координации вопросов прекращения огня и стабилизации линии разграничения сторон на основе использования инструментария ГИС и системы управления базами данных.

Ключевые слова: системы фиксации обстрелов, ГИС, СУБД.

\section{R. Tymoshenko, Ph.D;}

V. Fedoriienko;

O. Prokopenko

Center for Military and Strategic Studies of the National Defence University of Ukraine named after Ivan Cherniakhovsky, Kyiv

Aspects of the practical implementation of the model of the information-analytical system for fixing firings for the Ukrainian side of the JCCC

Resume. The article reveals the features of the practical implementation of the model of the informationanalytical system for fixing firings for duty service, the activities of the headquarters and Ukrainian observers of the Ukrainian side of the Joint Centre for Control and Co-ordination of issues of the cease-fire and the stabilization of the line of delineation of the parties, based on the implementation of GIS tools and database management systems.

Keywords: system of fixing of firing, GIS, DBMS. 